\title{
INNOVATION OF OIL PALM PLANT WASTE IN THE VILLAGE OF PLANTATION FOR LOSS OF DISTRICT SIRAPIT STEP DISTRICT
}

\author{
Rosnah Siregar $^{1}$, Hodriani ${ }^{*}$ \\ ${ }^{1}$ Faculty of Social Science, Universitas Negeri Medan, Medan, Indonesia \\ *Corresponding Author: hodrianis@yahoo.com
}

\begin{abstract}
The partner in the PKM program is the group of working housewives at Amal Tani Plantation village, Sirapit District, Langkat Regency. Based on the observation in the village, there are a lot of palm sticks wastes from the palm plantation. The interview carried out to the creative housewives resulted in some problems that they face, namely: (1) their husbands work only as the labor in the palm plantation, so the income is not sufficient for the family, (2) the knowledge of the women about the palm sticks waste from the palm plantation is still low, (3) the knowledge in business management is still low as well, (4) there are no special production tools in making tissue boxes, bags, and purses. The solutions proposed to solve the problem of the partner are: (1) empowering the group of creative housewives by using the resources in the village such as the sicks waste from the palm plantation for gardening rib-broom, bedroom rib- broom, plates, fruit basket, mineral water container, bag, and purse. (2) training about the rib waste from the palm plantation and the accompaniment followed-up by the practice to process the sticks waste from the palm plantation by presenting a competent source, (3) training and the accompaniment of business management in marketing and accounting, (4) providing the production tools and design making and the other kinds of handicraft made of rib waste from the palm plantation. The success of the service program will be measured from the output, such as: (1) the guidance of using the sticks waste from the palm plantation to become the gardening rib broom, bedroom rib broom, plate, fruit basket, tissue box, purse and bag, (2) product innovation from the sticks waste of the palm plantation, such as the yard broom, bedroom broom, plate, fruit basket, tissue box, purse and bag, (3) the report of the financial transaction in the cash book, (4) production tools to make the tissue box, purse, and bag by using ATBM.
\end{abstract}

Keywords: Empowerment, Accompaniment, Palm Stick Waste, Product Innovation.

\section{INTRODUCTION}

The Amal Tani Plantation village is one of the villages in Serapit District and is a village located in an oil palm plantation area. PT Amal Tani Medan is a private company engaged in plantation, industry, and trade. Amal Tani Plantation is domiciled in Bahorok District, Langkat Regency with the name Tanjung Putri plantation with its head office in Medan.

Based on the visit and interview with Mr. Muhammad Yakup as the Head of the Village of Tani Amal Plantation, information was obtained that, in 2016 the population of the Amal Tani Plantation Village was 1,792 people with a population density of 45 people per $\mathrm{km} 2$. The majority of the residents in Amal Tani Plantation Village work as plantation workers in PT Amal Tani with as many as 557 people, 10 people work in other fields, while the rest are economically unproductive residents. The area of the village is the largest of the 10 villages in the District of Sirapit, Langkat District, $39.49 \mathrm{~km} 2$ (40.09\%). (District of Sirapit in Figures 2017).

Based on observations on the territory of the Amal Tani Plantation Village, there were very many sticks from palm oil plantations which could be used as dishes. The existence of palm oil waste from oil palm plantations can be used as a source of additional family income. Efforts to obtain additional family income are deemed necessary to make improvements in the form of assistance. This assistance is a form of learning that leads to change so the role of an instructor is responsible for changes in the skills and attitudes of the person being trained. The human attitude and process are dynamic. The assistance will be given in the form of (1) utilizing natural resources around, (2) developing innovative and creative members, (3) making innovations from palm oil waste from oil palm plantations in groups of mothers working at PT Amal Tani.

Furthermore, based on the FGD with groups of housewives working to find out what village potential can be developed that can improve family welfare in the Tani Amal Plantation Village, it was found that palm oil waste from palm oil 
and fern plantations could be a potential village of Amal Tani. Some people have utilized palm oil waste from oil palm plantations as a source of additional family income, by selling palm oil waste from oil palm plantations after being cleaned from their leaves, but palm oil waste from oil palm plantations has not been utilized optimally by using it into innovative products from coconut plantation waste palm oil.

The women hope that there will be a kind of assistance in making, product innovation, types of products and business management accompanied by facilitation facilities for processing sticks from oil palm plantations into various plate creations, not just to make sticks into plates, they hope this assistance also has an impact on the family economy because it is accompanied by business management assistance, up to online sales. While their knowledge is about good business management is still lacking. So that there needs to be a joint effort so that mothers who work in managing the household become productive to increase the income of their families.

The partners of this community service activity are the Working Group of Housewives who are in PT Amal Tani, Sirapit District, Langkat Regency. In general, the mothers in this village take care of the household, while their husbands work as oil palm plantation laborers at PT. Amal Tani.

Based on mutual agreement with partners, priority issues that require solutions are: 1) Lack of family income from the income of plantation workers, 2) Lack of knowledge of mothers about palm oil waste from palm oil utilization and its utilization 3) Lack of good business management knowledge availability of special equipment for producing / manufacturing palm oil palm waste.

\section{SOLUTIONS AND OUTPUT TARGETS}

The solutions and outcomes to be achieved through this service program can be seen in Table 2.1 below,

Table 2.1 Solutions and Output to Achieve.

\begin{tabular}{|c|l|l|l|}
\hline No & \multicolumn{1}{|c|}{ Priority Problems } & \multicolumn{1}{|c|}{ Solutions } & \multicolumn{1}{c|}{ Output } \\
\hline 1. & $\begin{array}{l}\text { Lack of family income from the } \\
\text { income of plantation workers }\end{array}$ & $\begin{array}{l}\text { Empowerment of groups of } \\
\text { women utilizing the potential that } \\
\text { exists in the village, namely palm } \\
\text { oil palm leaf waste as a yard } \\
\text { broom, stick a broom in the } \\
\text { bedroom, dishes, fruit basket, } \\
\text { mineral water container, tissue } \\
\text { box, bag, and wallet. }\end{array}$ & $\begin{array}{l}\text { The fuide for utilizing } \\
\text { plantations becomes a yard } \\
\text { broom, bedroom broom, } \\
\text { plate, fruit basket, tissue } \\
\text { box, wallet and bag }\end{array}$ \\
\hline 2. & $\begin{array}{l}\text { Lack of knowledge of mothers } \\
\text { about utilizing the palm sticks } \\
\text { waste }\end{array}$ & $\begin{array}{l}\text { Training on palm oil palm waste } \\
\text { and mentoring was accompanied } \\
\text { by the practice of processing palm } \\
\text { oil palm waste by presenting } \\
\text { competent speakers. }\end{array}$ & $\begin{array}{l}\text { Product Innovation from } \\
\text { Palm Oil Plantation waste } \\
\text { in the form of yard } \\
\text { brooms, bedroom brooms, } \\
\text { plates, fruit baskets, tissue } \\
\text { boxes, wallets, and bags. }\end{array}$ \\
\hline 3. & $\begin{array}{l}\text { Lack of knowledge about good } \\
\text { business management }\end{array}$ & $\begin{array}{l}\text { Training and business } \\
\text { management assistance in the } \\
\text { field of marketing and financial } \\
\text { accounting. }\end{array}$ & $\begin{array}{l}\text { Financial } \\
\text { Report on Cash Book. }\end{array}$ \\
\hline 4. & $\begin{array}{l}\text { Unavailability of special } \\
\text { equipment for producing } \\
\text { manufacture tissue boxes, wallets, } \\
\text { and bags. }\end{array}$ & $\begin{array}{l}\text { Providing production and design } \\
\text { equipment and types of } \\
\text { handicrafts from palm oil palm } \\
\text { waste. }\end{array}$ & $\begin{array}{l}\text { Equipment for } \\
\text { producing/manufacturing } \\
\text { tissue boxes, wallets, and } \\
\text { bags with ATBM. }\end{array}$ \\
\hline
\end{tabular}

\section{IMPLEMENTATION METHOD}

This PKM activity uses the method of observation, education, training, practice and mentoring. The method of the approach taken is as follows:

a) Survey to partner locations to find out partner situations and problems.

b) Implementation of a Focus Group Discussion (FGD) with groups of housewives working to discuss activities to be carried out and determine the number of participants and the place of implementation of activities.

c) Program socialization to all group members.

d) The implementation of education and training on the manufacture of innovative products from sticks waste into yard brooms, bedroom brooms, plates, fruit baskets, tissue boxes, wallets, and bags.

e) Facilitation and practice of making innovative products from sticks waste into broomsticks, bedroom brooms, plates, fruit baskets.

f) Mentoring through making tissue boxes, wallets, and bags.

g) Handover of production equipment. 
h) Evaluation of activities that have been carried out.

\section{IMPLEMENTATION OF ACTIVITIES}

The implementation of this PKM activity takes place in three stages (1) Program socialization to all group members, (2) Implementation of education and training on making innovative products from sticky waste into yard brooms, bedroom broom brooms, plates, fruit baskets, tissue boxes, wallet and purse and (3) Assistance and manufacturing practices of innovative products from sticks of waste into yard brooms, bedroom brooms, plates, fruit baskets.

The stages of the implementation of education and training on the manufacture of innovative products from sticks into broomsticks, bedroom brooms, plates, fruit baskets, tissue boxes, purses, and bags can be exemplified through the implementation of education and training in making plates from sticks as follows:

1. Provide instructions on how to make sticky plates. Instructions on how to make sticky dishes are carried out by sharing through oral and written.

2. The training participants must master how to use and select sticks. The sticks used are Nipah sticks that have just been cleaned from the leaves.

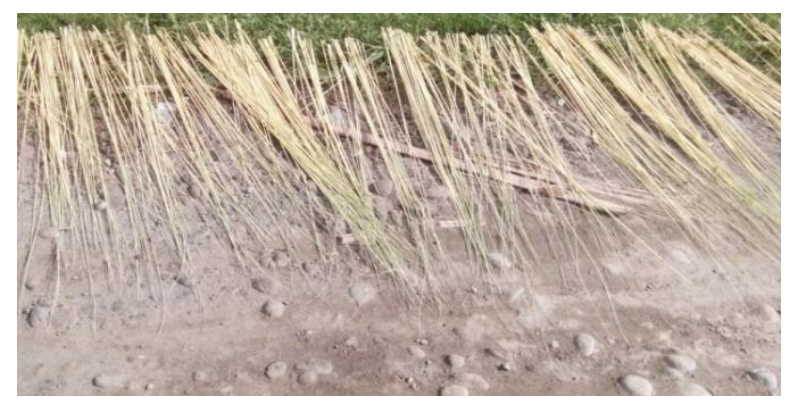

3. The stick used is usually a stick that is still wet.

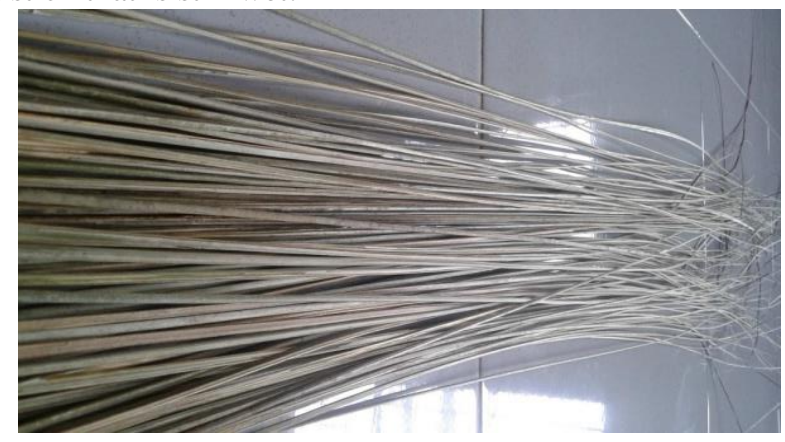

4. The sticks are sorted into 7 parts to assemble. Each section contains 12 sticks of the stick.

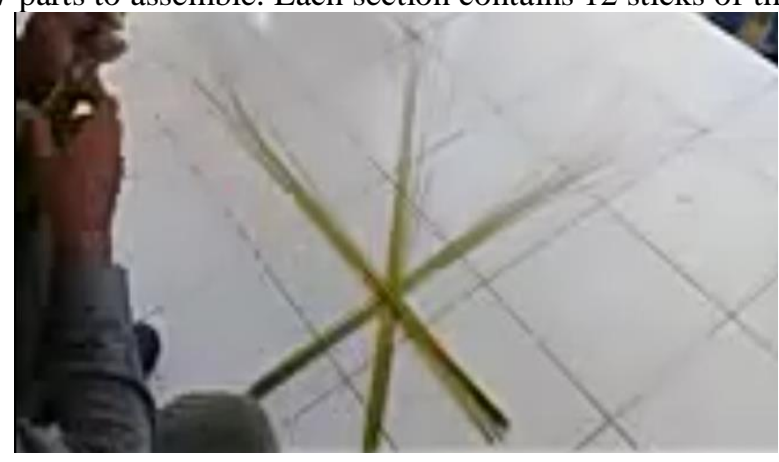


5. Woven starts from the middle by forming a certain pattern in the form of a circle.
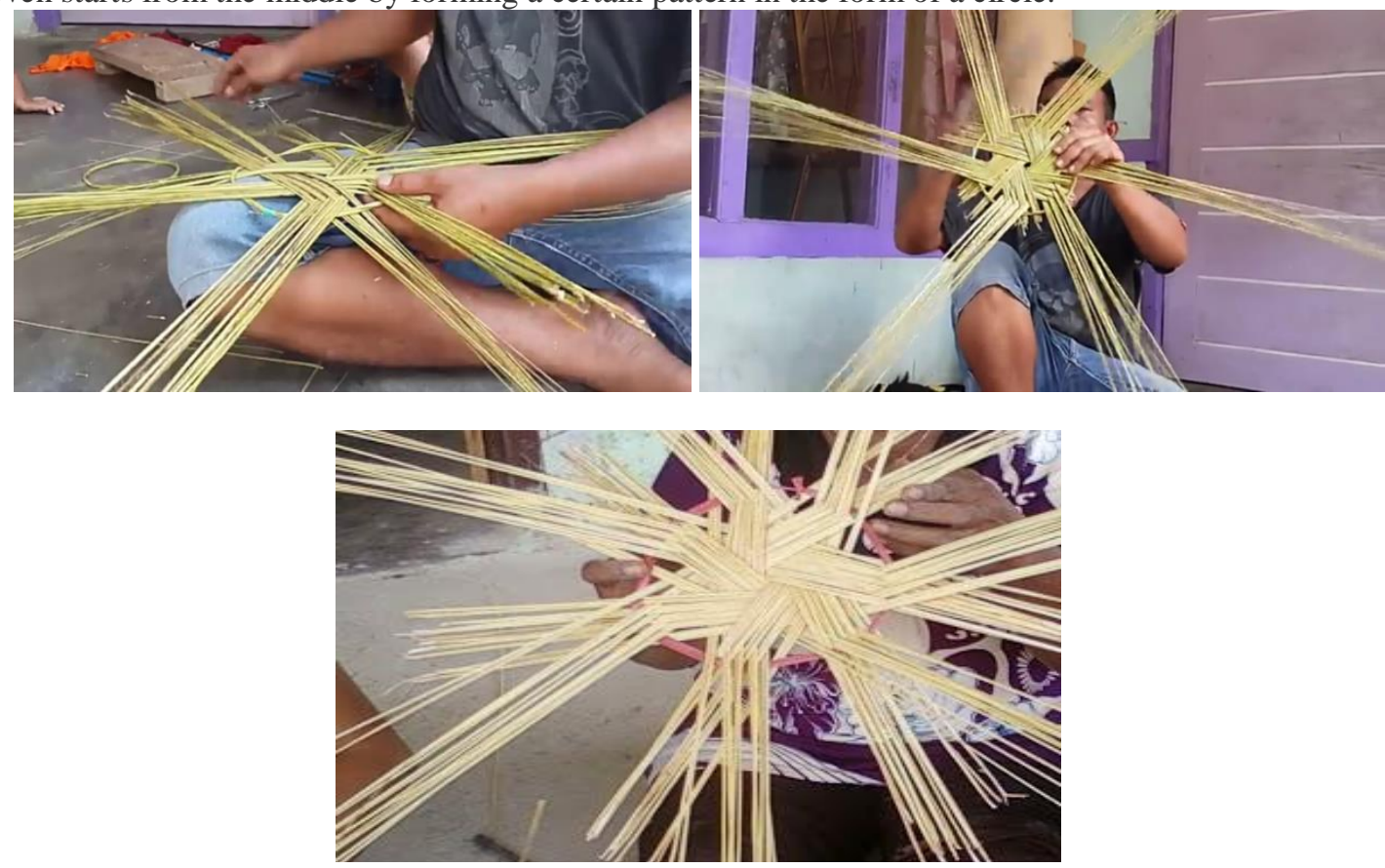

6. In accordance with the desired size, the stick is inserted at the end of the circle to form like a plate.

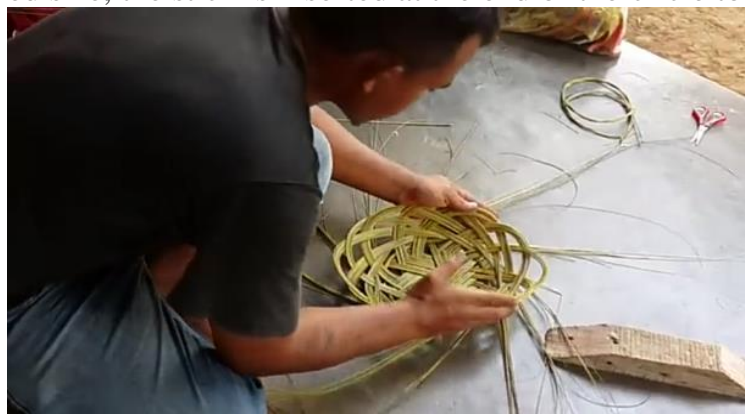

7. Pull the bottom to form a plate as you wish.

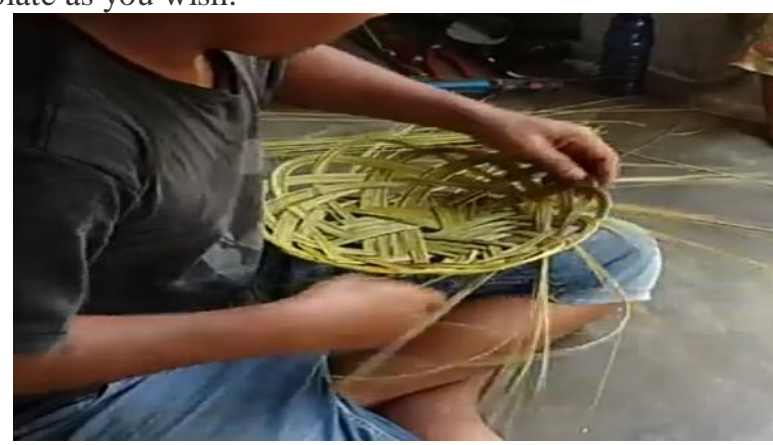

8. Cut the less neat bottom.

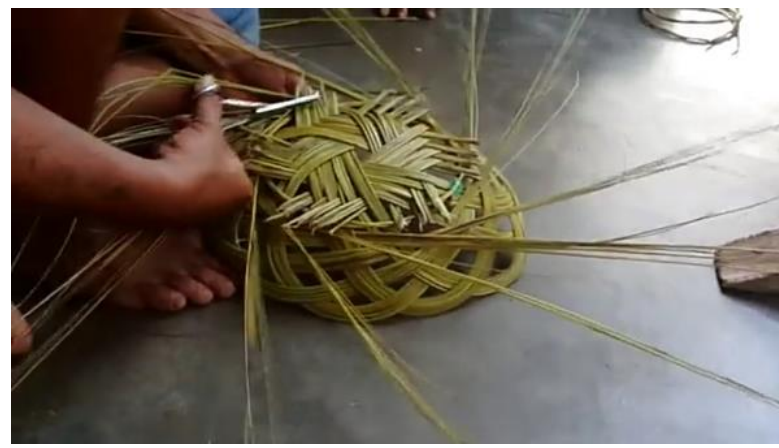


9. Start to form the woven from the leg.

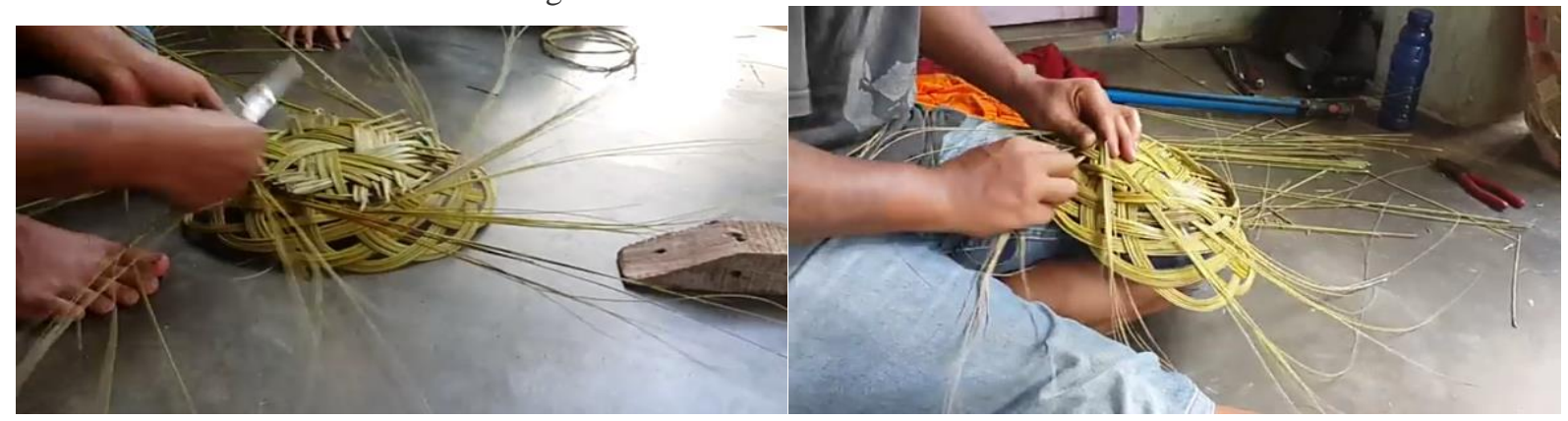

10. Cut the excess parts of the leg.

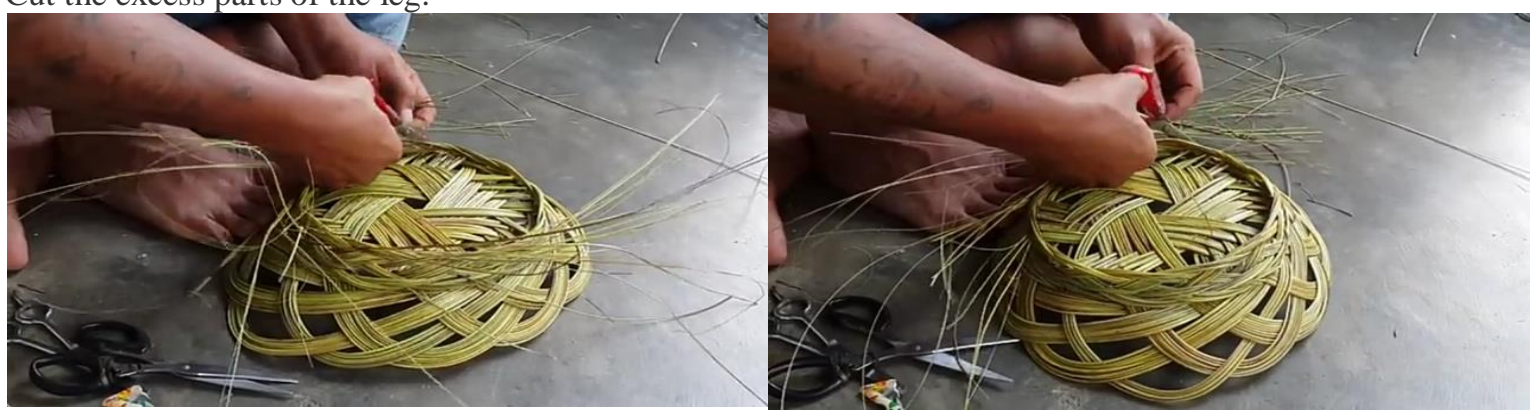

11. Finishing, with varnish, paint, or melasmic process.

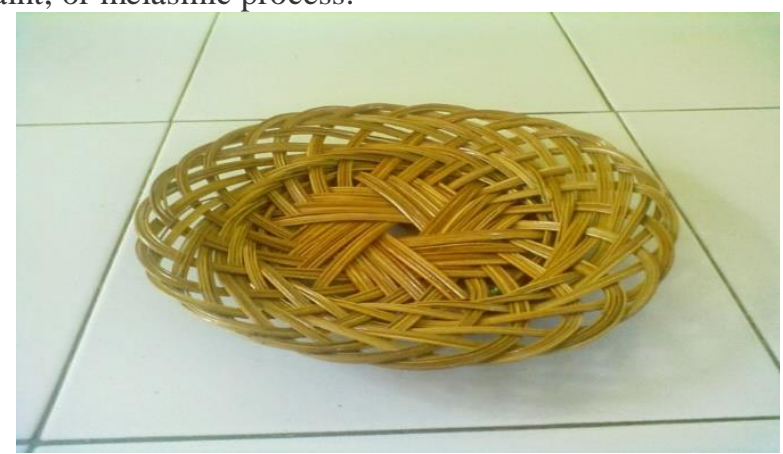

12. The handicraft made by the women.

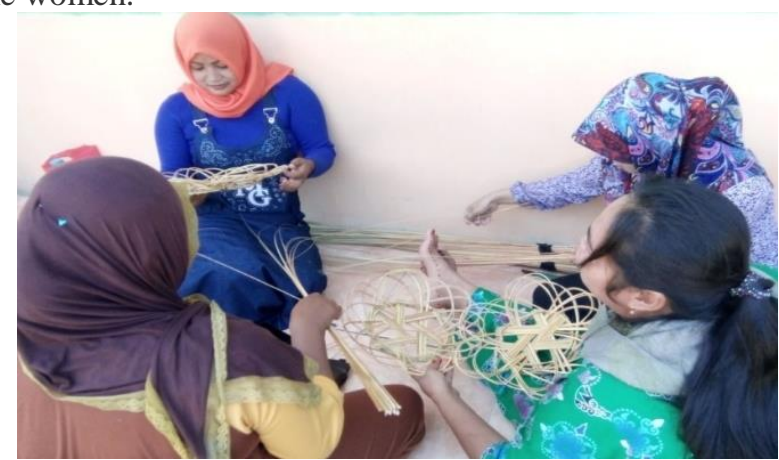

\section{PROGRAM EVALUATION}

The program evaluation that will be carried out by the service team in partner groups includes:

1) Early Stage

a) Evaluate partners' understanding of the making of innovative products from sticks waste into yard brooms, bedroom broom brooms, plates, fruit baskets, tissue boxes, wallets, and bags.

b) Evaluating partners' understanding of the making of innovative products from sticky waste into broomsticks, bedroom brooms, plates, fruit baskets

2) Implementation Stage 
a) Evaluating partners to understand the process and practice of making innovative products from sticky waste into broomsticks, bedroom brooms, plates, fruit baskets.

b) Supervise the use of production equipment provided.

3) The Final Stage

Measuring indicators of increasing family income for groups of housewives working. When experiencing success, it will be carried out with further development activities.

\section{PROGRAM SUSTAINABILITY}

The sustainability of the program after the community service program is carried out on partners, namely: Making partners as MSMEs assisted by the UNIMED Community Service Agency. The partner business profile will then be included in the LPM database so that partner products can be seen on the LPM website. This will help partners in promoting partner products namely yard brooms, bedroom brooms, plates, fruit baskets, tissue boxes, purses, and bags. Conducting the guidance and assistance by UNIMED LPM in accordance with the programs planned by the LPM each year through PO-DIPA funding from Medan State University or Village Partner Development Program. 